\title{
DOES THE LOCAL ECONOMIC GOVERNANCE IN INDONESIAPERFORM AN IMPROVEMENT?
}

\author{
Haryo Kuncoro ${ }^{1}$
}

\begin{abstract}
Governance has gone through radical changes over the last twenty five years. Seemingly, it became one of the important strategies, processes, methods and mechanisms in governing countries to achieve economic development goals. The objective of this paper is to observe the local economic governance dynamics in the case of districts/municipalities in Indonesia. First, the dynamics behavior of local governance over time is analyzed by visual inspection of their non-parametric density distribution. More deeply, we use Markov chains to predict a pattern of change in local economic governance toward its steady state. Based on comparison between 2007 and 2011 data delivered by Commission of Regional Autonomy Implementation Watch, we conclude that there is a high level of persistence in the relative position of local governance index, consistent with a low degree of mobility in the index distribution implying the implementation of governance in the districts/municipalities in Indonesia is weak enough. This finding implies that the local economic governance is a key to achieve sustainable regional economic growth in line with fiscal decentralization and regional autonomy.
\end{abstract}

Keywords: Local Economic Governance, Decentralization, Regional Economic Growth, Kernel Densities, Markov Chains

JEL Classification: H70, O43, O56

1 Lecturer at Faculty of Economics, State University of Jakarta; har_kun@feunj.ac.id. Author would like to thank a unanimous BEMP reviewer for his/her constructive comments. Earlier version of this paper has been presented in the 11th Indonesian Regional Science Association (IRSA) Conference held by Faculty of Economics, Lambung Mangkurat University on July, 9-10, 2012 in Banjarmasin, South Kalimantan, Indonesia. My acknowledgement also goes to all participants for invaluable suggestions. However, any error, shortcoming, and confusion which may remain are my responsibility. 


\section{INTRODUCTION}

Regional developmentis essentially an integral part of the national development. The regional development is directed to achieve the national targets that are adjusted to the potential, aspirations, and problems of development in the region. Therefore, the achievement of the national developmentis a shared responsibility among the central, provincial, and district/ municipalities governments so that the national development is asynergic aggregation of the regional development performance (Hariyoga, 2009).

Within that framework, since 2001 the government of Republic of Indonesia has been implementing the fiscal decentralization and regional autonomy policies. Those policies are based onthe fact that a broad area such Indonesia which each region has variety conditions and specific economic potencies. Within the fiscal decentralization and regional autonomy policies, the regions are expected to develop local economic potencies more effectively and efficiently (Kuncoro, 2005).

In macroeconomic perspective, the potency of those local economies is a necessity for national strategy in order to improve the quality of national economic growth. In principle, the local economic potencies engage the regional and bottom-up approaches, which in turn could be a correction for industrial approach which had been used by the previous regime. In addition, the majority ofeconomic actors are small and medium enterprises reaching 44.7 million people or 99.9 percent of the total employment in Indonesian manufacturing industry and they are local resources basis. Thus, the local economies potencies can overcome the problem of unemployment, poverty, andimprove the national economic resilience (Sebayang and Kuncoro, 2011).

The success of the local economic potencies will depend on the regions in structuring and managing their own localities, including improving the investment climate and attracting investors within the fiscal, political, and administration decentralizations frameworks (Mahi, 2009). The average of regional economic growth in the decentralization period performed an improvement. However, relative to the decentralization (e.g. the period 1993-1996) the economic growth after the decentralization was still lower. The decentralization also spawned the growth of regions is relatively high, compared to the national average; however, some areas require the acceleration of growth (Lewis, 2003). In the second half of 2000s, the regional economic growth and income distribution across locality relatively remain unchanged (Figure 1 and 2).

Those facts confirm the necessity of local government behavior changes to facilitate local economic potencies in order to achieve the sustainable living standard improvement (Kaufmann etal.,2005; Knack,2003). This paper would like to examine the dynamics of local economic governance in the case of districts / municipalities in Indonesia. This paper will begin with are view of the relevant literature regarding the governance. This is followed by exploring the empirical evidence concerning the influence of governance on the local economic 


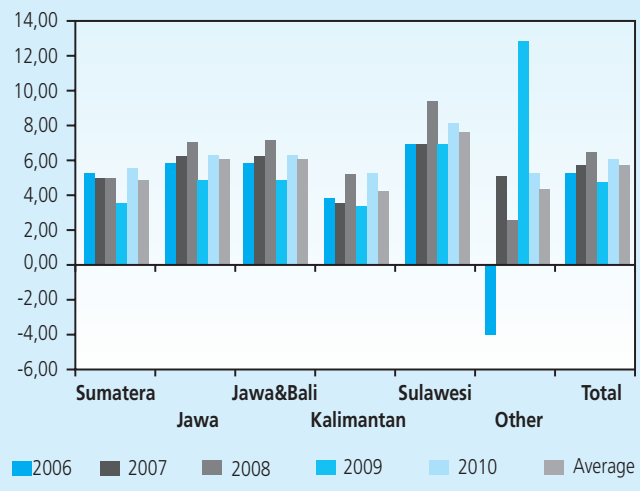

Figure 1

Regional Income Growth

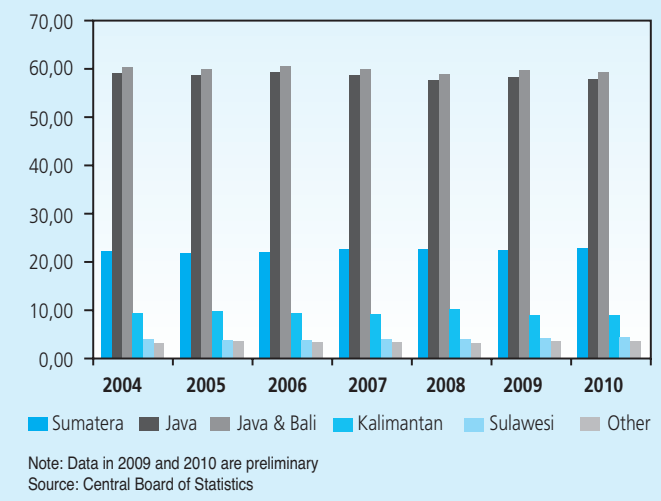

Figure 2

Regional Income Distribution

performance. The assessment data for Indonesia is placed in the next section. Finally, some concluding remarks are drawn.

\section{THEORY}

Political economics literature offers a huge intrepretations regarding governance which nowadays is still in process to reach a general concensus. Broadly speaking, governance is defined as the traditions and institutions that determine how authority is exercised in a country (Kaufmann et al., 2000). Weiss (2005) noted that governance is related to strategies, processes, methods, and mechanisms in governing countries and achieving public demand and interest.

Weiss (2005) further explained that good governance has been associated with democracy and good civil rights, with transparency, with the rule of law, and with efficient public services. Governance also involves the interaction between formal institutions publicly and privately and those of civil society. Similarly, Chibba (2009) pointed out that governance matters have been an integral part of societies since the dawn of civilization, and especially so with respect to what values, ethics and rules of conduct, and justice should be upheld, how societies should be organized, and who should hold power and authority.

Some definitions above are complementary with each other and clearly propose the same basic idea of governance. However, theyare still in the area of political science, i.e. have less economic meaning. In the context of economics, Dixit (2001) pointed out that economic governance consists of the processes that support economic activity and economic transactions by protecting property rights, enforcing contracts, and taking collective action to provide appropriate physical and organizational infrastructure. Tong (2011) simply defined governance quality as the capacity of a government to internalize externality. Even though the Dixits' and 
Tongs' definitionsare still general, they providea useful starting point to explore the more detail concepts.

Other scholars have narrowed the lens somewhat, disentangling governance into separateconcepts, such as corruption (Wei, 2000), transparency (Kaufmann et al., 2000), regulation (Djankov, et al., 2002), and public goods provision (Kaufmann et al., 2005), that each themselves still contain a number of different policy levers and types of interactions. Other scholars have taken a micro perspective where individual policies such as business registration procedures have been isolated and explored separately from other modes of governance in society (see:for instance Helpman (2008) for several recent studies).

Based on some extended interpretations above, one important thing that could be inferred isthat the government's capability in managing its administration will bring a critical impact on all economic agents' activities. Even though the concept of governance is not new, it is as old as human civilization, unfortunately, this factoris considered to be given intraditional neoclassical economic growth model, as in the proposition of Solow (1956), Cass(1965), and Koopmans (1965) (see: Romer, 1996). The endogenous growth theory proposed by Romer $(1986 ; 1990)$ and Lucas (1988) tried to incorporate the factors of innovation without explaining how and where the innovation can be created. The technological innovation can only becreated because of institutional environment.

A link connecting among institution, governance, and economic performance has been a subject of intense discussion for the last 25 years. The seminal work of North (1981) could be considered as pioneer the emerging idea of government capability inducement. According to North (1981) institutions are the rules of the game in a society or, more formally, are the humanly devised constraints that shape human interaction. The constraints would affect through incentives (North, 1990). In this circumstance, the incentive is understood as conditioning the willingness of economic actors to accept the rule of the game.

Since that, a numerous economists develop the North's idea in creating incentive in order to promote economic growth using different perspectives. In principle, they have the same objectives, i.e. reducing uncertainly and promoting efficiency. The New Political Economy, for example, argued the need of structural adjustment programs by remove the incentives for rent seeking and corruption (Krueger, 1974; Posner, 1975; Bhagwati, 1982; Bardhan, 1984; Colander, 1984; Alt and Shepsle, 1990; Lal and Myint, 1996; Bates, 2001).

In line with the New Political Economy, the New Institutional Economy (initiated by Williamson, 1975; 1985) had brought to the fore economic theories thatidentified governance capabilities that states needed to have to create the conditionsfor low transaction cost (efficient) markets.In principle, the New Institutional Economics emphasized the importance of marketenhancing government throughcontracts enforcement and property rights protection.In short, Acemoglu, Johnson, and Robinson (2005)concluded that good government governance is a fundamental cause of long run economic growth. 
Although there is no governance without government, governance cannot be judged solely on outcomes but must also consider the processes and relationships that produce them, however. More operationally, some expert teams develop indices to accommodate various concepts of the economic governance above (for example Knack and Keefer, 1995, 1997; Kaufmann et al.,1999, and Kaufmann et al.,2005). World Bank (2005) recently summarized them into six broad governance indicators. These are:

1. Voice and Accountability - measuring political, civil, and human rights

2. Political Instability and Violence - measuring the likelihood of violent threats to, or changes in, government, including terrorism

3. Government Effectiveness - measuring the competence of the bureaucracy and the quality of public service delivery

4. Regulatory Burden - measuring the incidence of market-unfriendly policies

5. Rule of Law - measuring the quality of contract enforcement, the police, and the courts, as well as the likelihood of crime and violence

6. Control of Corruption - measuring the exercise of public power for private gain, including both petty and grand corruption and state capture.

The six indicators above suggest that governance quality is a complex notion. It can take many forms and there may be trade-off between different dimensions of governance.As noted by Tong (2011), however, good governance is often loosely described as effective government, which is a broad and multi-dimensional concept itself. Various widely used governance indicators do not provide an all-encompassing definition. Thomas (2007) describes the various indicators as a result of the mixed "personal ideas of governance" put forward by people developing them. Quibria (2006) points out that governance is often "used as an umbrella concept to federate a whole assortment of different, albeit related, ideas".

Regardless the different dimensions of governance, the convergence of those different perspectives led to the emergence of a set of policy priorities for governance that has come to be known as the good governance agenda.Empirical studies regarding the good governance have been conducted widely. In general, they support to close correlation or even causal relationship between institutional governance and economic performance.

In the cross-country level, some determining factors which have been identified in particular researches are property rights and entrepreneurial activity (Galiani and Scargrodsky, 2006; Di Tella, 2007; Fields, 2007; Banerjee and lyer, 2005; and Malesky and Taussig, 2009). Mengistu and Adhikary (2011) considered good governance as a key determinant for foreign investors to invest their fund in the case of Asian countries.

Other scholars have devised clever sub-national analyses of the impact of corruption on economic behavior (Fisman, 2001; Golden and Picci, 2005; Di Tella and Schargrodsky, 2003; and 
Olken, 2007), the importance of state-business relations (Cali, 2009) as well as the predictability of corruption (Malesky and Samphantharak, 2008). Ardagna and Lusardi (2008) show that better contract enforcement institutions increase the share of entrepreneurs that identify themselves as growth-oriented. Using variance in institutions across provinces in Mexico, Laeven and Woodruff (2007) find a significant relationship between better contracting institutions and higher levels of growth in firm size.

Most studies above have focused on cross-country data which differ from Indonesia that has a unique economic characteristics and culture. According to Lewis (2003), the economic performance of Indonesia's districts since decentralization in 2001 has varied dramatically. Some districts have seen steady economic progress, strong investment, and job creation. But many others have lagged behind, failing to share in overall economic growth. Moreover, there is evidence that the policies pursued by sub-national authorities have had an important bearing on the quality of the local investment climate (Lewis 2003).

Kuncoro and Suryanto (2003) found that there was a high level of persistence in the relative position of regional income, consistent with a low degree of mobility in the income distribution. The richest regions tend to polarize gradually, which may be attributed to externalities linked to localization or to the proximity the rest of Java. Pepinsky and Wihardja (2009) also suggest that divergent economic performance across districts/municipalities is driven by heterogeneity in endowments, factor immobility, and institutional quality. Those findings confirm to study of Mahi (2009). He found that even though the geographical concentration of industries gradually decreased (especially in Java and Bali) after decentralization, it has a bad impact on the regional economic development equality. He also found that investment climate played an important role in the geographical concentration.

Istiandari (2009) assessed the local economic governance and related it to regional income as well as poverty rate. According to her study, most regions in Java had a higher governance rate to provide a positive impact on welfare. She also found that there was a large disparity of governance implementation among districts/municipalities. Most recently, McCulloch and Malesky (2010) exploit a new dataset of firm perceptions of the quality of economic governance in 243 districts across Indonesia to estimate the impact of nine different dimensions of governance on districts/municipalities growth. Surprisingly, they found relatively little evidence of a robust relationship between the quality of governance and local economic performance.

Numerous studies above suggest that the local economic governance matters for the regional economic performance. So, it is urgent for us to investigate the local economic governance. For point of view of researchers, it is an important test for the validity of the New Political and New Institutional Economics when confronted with the Neoclassical and Endogenous Growth models. Policy makers, in turn, consider governance also as crucial issue and a new dimension to the administration and policy studies and planning for countries globally.Moreover, sub-national analysis of this kind is becoming increasingly relevant for policy as many countries 
move towards greater political, fiscal, and administrative decentralization. Indeed central governments and donor agencies often have an explicit objective of improving governance at the sub-national level on the grounds that this will improve local economic growth.

This paper contributes to the local government governance literature and empirics particularly to Indonesia. Our approach is in the same spirit with Istiandari (2009) and McCulloch and Malesky (2010), although it has three significant differences. First, we observe the governance indices instead of estimating directly governance indicators to regional economic growth. Second, we focus on the transition dynamics of relative governance indices using non parametricmethod (i.e. Kernel density function) to identify the pattern of governance distribution across countries. Third, we focus on the transition dynamics of relative governance distribution using Markov chains. This paper also detects some particular changes in the movement of local economies governance according to their index ranks. The use of Markov chains which intensively has been employed in business research is intended to offer a deeper analysis of local economic governance dynamics process in Indonesia.

\section{METHODOLOGY}

To have a better understanding about the shape of the relative local governance distribution or how it evolved over the years in Indonesia, the Kernels of the actual relative local governance in different time periods are estimated so that their shapes and inter-temporal dynamics can be studied. A Kernel estimator of a set of observations - in this case the relative rankings of the local economic governance index - is an estimated distribution function from which the observations are likely to have been drawn (for details, see Silverman (1986)). Mathematically, the Kernel estimator $f(x)$ is defined as

$$
f(x)=1 / N h \Sigma j=1 \quad--->\quad N K[(x-X j) / h]
$$

where,

$X_{j}=$ data

$N=$ number of data points

$h=$ window width/smoothing parameter

$K=$ Kernel/weighting function (assumed to be the normal distribution in this paper)

The Kernel density estimation requires several steps (see Silverman, 1986). In the first step, in each year, the sub-index of each district/municipality was re-scaled as a fraction of the national average the associated sub-index, such that the distribution is restricted to lie in the positive values. Since by construction, the national average sub-index is always 1 (100 percent). 
In the next step, for a suitably large number of points spanning the interval, the relative frequency, i.e. the unconditional probability, with which each of these values could have occurred, was estimated. The probability of each point was computed as the weighted average of the distance of that points from the given relative incomes of all the regions, with the weights drawn from a normal or Gaussian distribution centered at that point. Weights drawn from anEpanechnikov distribution, which is the other frequently used weighting method, did not seem to make any material difference to the shape of the estimated Kernels.

In the third step, the relative frequencies of these points were filtered for noise using the procedure in Silverman (1986). The collection of the filtered relative frequencies formed the Kernel of the relative local governance in that year. The area of the distribution was normalized to 100 (percent). The Kernel estimators tell us how likely it is that governance score, on average, was a certain fraction of national average governance score in a particular year.

As stated above, the Kernel density distribution is helpful to identify the shape of the relative governance distribution or how it evolved over the years. But it can not predict each transition probability of the distribution will converge toward each steady state. Markov chains offer the transition probability of each distribution to achieve each steady state. Markov processes can be considered as a special case of stochastic processes. They can be defined in continues of discrete time and relate to a continuous or discrete set of states.

Following Amemiya (1985), a Markov model can be characterized by the following two properties:

- A sequence of binary random variables taking the values $\mathrm{y}_{\mathrm{j}}(\mathrm{t})=1$ if the $i^{\text {th }}$ unit is the state $j$ at time $t$ and $\mathrm{y}_{\mathrm{j}}(\mathrm{t})=0$ otherwise, for $i=1, \ldots, \mathrm{n}$

If, in a discrete-time context, for each unit $i$, the distribution of the vector $\mathrm{y}_{\mathrm{j}}(\mathrm{t})$ depends fully and only on $\mathrm{y}_{\mathrm{i}}(\mathrm{t}-1)$, then the process is a first-order discrete-time Markov process.

- A set of transition probabilities, in which $\mathrm{pi}_{\mathrm{jk}}(\mathrm{t})$ denotes the probability of unit $i$ being in the state $j$ at time (t-1) and jumping to state $k$ at time $t$. If the set of states is finite and denumerable then all the transition probabilities may be ordered in the form of the socalled Markov matrix. $\mathrm{Pi}=\{\operatorname{pijk}(\mathrm{t})\}$, in which the sum of all the element of a row will add up to one.

Let $\mathrm{p}(\mathrm{t})$ be the vector describing the distribution of the units over the different states at moment $t$. It holds of course that

$$
\mathrm{p}_{\mathrm{j}}(\mathrm{t})=1 / \mathrm{n} \Sigma_{\mathrm{i}-1-\mathrm{-}-\mathrm{n}} \mathrm{yi}_{\mathrm{j}}(\mathrm{t})
$$

where $\mathrm{n}$ is the number of units. Such model is called a Markov chains. 
Furthermore, if the transition probabilities do not depend on time or on the unit, the model is called homogenous and stationary. It can be shown that, under fairly general conditions, there exists a uniquely defined long run, or 'ergodic', matrix of transition probabilities $\mathrm{P}$ and a corresponding vector of equilibrium probabilities associated to a stationary Markov chains. More formally, if we denote the transition matrix by $\mathrm{P}=\left\{\mathrm{p}_{\mathrm{jk}}\right\}$, then the 'ergodic' equilibrium vector is $\pi$, verifying

$$
\pi=p^{\prime} \pi
$$

Such that

$$
\pi_{\mathrm{j}} \geq 0 \text { and } \Sigma_{\mathrm{j} \in \mathrm{E}} \pi_{\mathrm{j}}=1
$$

It follows that

$$
\lim _{t \rightarrow \infty} p_{j}(t)=\pi_{j}
$$

In other words, in the long run the elements of the transition matrix will reach the state of nature $\mathrm{j}$ with probability $\pi_{\mathrm{j}^{\prime}}$ irrespective of the starting position. If we consider a finite number of states (as determined, for example, by different levels of index rank), the shift of the units among states can be easily traced and, therefore, the transition probability matrix can be obtained.

This matrix will show the dynamic behavior of the units, since the transition matrix expresses, roughly speaking, and the probability of a unit starting off in a particular state and ending up in the same or in a different state. Notice that, by means of using first-order Markov chains, it is implicitly assumed that all the relevant information about the past behavior of a particular region is embedded in its fundamentals underlying the steady state towards which a region converges are fairly stable over time.

We can apply, again following Amemiya (1985), the rule that the maximum likelihood estimator of the transition probabilities can be computed as follows:

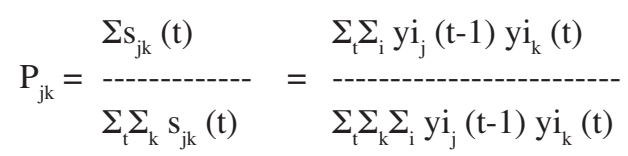

in which $\mathrm{s}_{\mathrm{jk}}(\mathrm{t})$ denotes the number of units that have changed from state $\mathrm{j}$ to state $\mathrm{k}$ in period t. The ergodic vector, that describes the index distribution of the units in the long run, is obtained 
by means of iterating the transition matrix. If the ergodic density vector has only one maximum, it suggests some degree of convergence. Instead, if it tends to a bi-modal (or even tri-modal) structure it may be pointing to some degree of polarization.

The nature of this analysis, however, suggests that results regarding the steady state governance index distribution should be looked at with some caution. The computation of long-run probabilities implicitly implies that historic probabilities will somehow carry over in the future. In other words, there is no place for shocks to alter the course of this economy and change the current trend. This surely is unrealistic; there is no reason to believe that institutions, the rate of technological progress, the nature of human capital, and other crucial factors determining local economic governance index will remain constant over time.

\section{RESULTS AND ANALYSIS}

This paper used local economic governance data published by Commission of Regional Autonomy Implementation Watch (Komisi Pengawas Pelaksanaan Otonomi Daerah, KPPOD). Since 2007, the Asia Foundation, in conjunction with a national Indonesian NGO, KPPOD, has been launching data set of firm perceptions which measures the quality of local economic governance in 243 districts across the country. The data is based on a statistically representative random sample of over 12,000 firms and 729 business associations throughout these districts/municipalities. The selected firms cover small (those have 10-19 workers), medium (those have 20-99 workers), and large (those have more than 100 workers) industries. The proportion is 50,45 , and 5 percent respectively.

We use 2007 data and compared with the latest 2011 data. The Local economic governance indicators used by KPPOD comprise 9 elements following World Bank (2005) criteria:

1. Land Accessibility

2. Business Licensing

3. Interaction between Local Government and Private Sector

4. Business Development Programmes

5. Capability and Integrity of Local Government Officials

6. Local Taxes and Local Retributions and other Transaction Costs

7. Infrastructure Management

8. Security and Conflict Resolution

9. Quality of Local Regulations

Each criterion then is calculated into sub-indicesrespectively as well as total index. In constructing those indices KPPOD used judgment, analytical hierarchy process, and finalized 
by focus discussion group. Each index ranges from 0 to 100 points. The higher the index, the better the governance is. Based on the total index, KPPOD then ranks all regions consecutively as presented in Table 1. During 2007-2011, Blitar was the number one both in the two periods. Magetan and Probolinggo also lied in ten top ranks.

\begin{tabular}{|c|c|c|c|c|}
\hline \multicolumn{5}{|c|}{$\begin{array}{c}\text { Table } 1 . \\
\text { Ten Top of Local Economic Governance Total Index Rank in 2007-2011 }\end{array}$} \\
\hline Rank & Region & 2007 & Region & 2011 \\
\hline 1 & Blitar District & 76.00 & Blitar District & 80.50 \\
\hline 2 & Magetan Municipality & 75.40 & Lampung Utara Municipality & 79.00 \\
\hline 3 & Prabumulih District & 74.70 & Probolinggo District & 78.40 \\
\hline 4 & Musi Banyu Asin Municipality & 74.30 & Batu District & 76.30 \\
\hline 5 & Jembrana Municipality & 73.70 & Sorong Municipality & 74.60 \\
\hline 6 & Tuban Municipality & 73.40 & Bangka Tengah Municipality & 74.30 \\
\hline 7 & Lumajang Municipality & 72.00 & Magetan Municipality & 73.90 \\
\hline 8 & Madiun Municipality & 72.00 & Probolinggo Municipality & 73.80 \\
\hline 9 & Probolinggo District & 71.50 & Solok District & 73.20 \\
\hline 10 & Gianyar Municipality & 71.30 & Padang Panjang District & 73.10 \\
\hline
\end{tabular}

Table 2 broke down further into two main characteristics of regions. Referring to the main island, the average of total index of local economic governance in Java (64.32) is much higher than that in outer Java (59.82). In 2011, it did not change. The local economic governance index in Java increased faster than in outer Java. It seems that Java, where the industry concentrate geographically, has relatively better local economic governance. Consequently, it has a bad impact on the regional economic development equality as stated by Mahi (2009).

\begin{tabular}{|c|c|c|c|c|c|}
\hline \multicolumn{6}{|c|}{$\begin{array}{c}\text { Table } 2 . \\
\text { Descriptive Statistics of Local Economic Governance Total Index 2007-2011 }\end{array}$} \\
\hline & & Java & Outer Java & District & Municipality \\
\hline \multirow{3}{*}{2007} & Mean & 64.32 & 59.82 & 61.75 & 61.70 \\
\hline & Std. Dev & 4.85 & 6.76 & 6.62 & 6.38 \\
\hline & Obs & 102 & 141 & 55 & 188 \\
\hline \multirow{3}{*}{2011} & Mean & 67.11 & 61.79 & 65.94 & 62.12 \\
\hline & Std. Dev & 6.12 & 7.23 & 5.95 & 7.43 \\
\hline & Obs & 46 & 199 & 43 & 202 \\
\hline
\end{tabular}


Based on the administrative region, the average of local economic governance in districts (61.75) relatively equals to that in municipalities (61.70). However, in 2011, the average of local economic governance in districts grew higher than that in municipalities, consistent with study of Istiandari (2009). Moreover, the variability of the average of local economic governance in municipalities was larger than that in districts indicated by higher standard deviation to mean ratio. These imply that the unequal economic governance exist either in Java-outer Java or in district-municipality, consistent with unequal regional income as found by Kuncoro and Suryanto (2003).

Table 3 provides the descriptive statistics the 9 sub-indices for 2007. The highest is score on the Quality of Local Regulations $(X 9,84.22)$. The two lowest score are on Business Development Programs $(X 4,43.04)$ and the Interaction between Local Government and Private Sector $(X 5,56.92)$. On the average the local economic governance total index is relatively moderate about 61.72 and standard deviation is 6.42 points. Looking at the coefficient of variation ( $C V$, standard deviation to mean ratio), all of the indices do not vary around the mean value.

\begin{tabular}{|c|c|c|c|c|c|c|c|c|c|c|}
\hline \multicolumn{11}{|c|}{$\begin{array}{l}\text { Table } 3 . \\
\text { Descriptive Statistics of Sub-Indices of Local Economic Governance } 2007\end{array}$} \\
\hline Sub-Indices & $\mathrm{X} 1$ & $\mathrm{X} 2$ & $\mathrm{X} 3$ & $\mathrm{X} 4$ & $\times 5$ & X6 & X7 & X8 & X9 & Total \\
\hline Mean & 71.26 & 59.95 & 55.42 & 43.04 & 56.92 & 69.55 & 65.57 & 60.01 & 84.22 & 61.72 \\
\hline Median & 71.70 & 60.00 & 55.40 & 41.80 & 57.40 & 70.50 & 67.00 & 61.90 & 88.20 & 62.10 \\
\hline Max. & 99.40 & 84.60 & 80.10 & 86.50 & 87.90 & 96.10 & 89.00 & 96.70 & 100.00 & 76.00 \\
\hline Min. & 39.70 & 32.20 & 26.30 & 15.00 & 23.90 & 27.30 & 26.30 & 27.40 & 1.10 & 41.40 \\
\hline Std. Dev. & 10.25 & 8.33 & 9.84 & 12.14 & 10.82 & 12.24 & 12.06 & 11.51 & 13.92 & 6.42 \\
\hline CV & 0.14 & 0.14 & 0.18 & 0.28 & 0.19 & 0.18 & 0.18 & 0.19 & 0.17 & 0.10 \\
\hline Skewness & -0.39 & -0.20 & -0.19 & 0.58 & -0.09 & -0.32 & -0.59 & -0.18 & -1.93 & -0.43 \\
\hline Kurtosis & 3.85 & 3.66 & 3.16 & 3.86 & 3.57 & 2.94 & 2.98 & 2.87 & 8.87 & 3.08 \\
\hline J-B test & 13.56 & 6.09 & 1.67 & 21.22 & 3.62 & 4.13 & 14.30 & 1.52 & 499.92 & 7.62 \\
\hline Prob. & 0.0011 & 0.0475 & 0.4337 & 0.0000 & 0.1639 & 0.1267 & 0.0008 & 0.4669 & 0.0000 & 0.0222 \\
\hline Obs. & 243 & 243 & 243 & 243 & 243 & 243 & 243 & 243 & 243 & 243 \\
\hline
\end{tabular}

Table 3 also shows the shape of the distribution. All sub-indicess lightly skewed to the left, as indicated by the negative value of skewness (except $X 4$, Business Development Program). In terms of sharpness, the polygon frequency is likely to mesokurtic shape as shown by the value of kurtosis around 3. The Quality of Local Regulations (X9) sub-index is an 
exception. The value of kurtosis is the highest, 8.87, displaying leptokurtic shape of its polygon frequency.

Table 4 shows the descriptive statistics for 2011. The interesting thing is the average of governance index of Local Taxes and Local Retributions and other Transaction Costs (X6) currently it becomes the highest (81.28) in 2011 slightly higher than that of Quality of Local Regulations (X9). It appears that there is a significant improvement for local governments to revise their regulations. According to KPPOD (2011), during 2001-2010 the central government (i.e. Ministry of Finance) assessed 13.252 local regulation drafts, 4.885 drafts were recommended to Ministry of Home Affairs to be canceled. Ministry of Home Affair has already officially canceled only 1.843 local regulations especially regarding taxes and levies regulations. The remaining regional regulation drafts have not been decided yet whether canceled, held, or suspended.

\begin{tabular}{|c|c|c|c|c|c|c|c|c|c|c|}
\hline \multicolumn{11}{|c|}{$\begin{array}{l}\text { Table } 4 . \\
\text { Descriptive Statistics of Sub-Indices of Local Economic Governance } 2011\end{array}$} \\
\hline Sub-Indices & $\mathrm{X} 1$ & $\mathbf{X} 2$ & X3 & $\mathrm{X} 4$ & $\times 5$ & $x 6$ & $\mathbf{X 7}$ & $X 8$ & X9 & Total \\
\hline Mean & 73.77 & 62.22 & 50.94 & 38.57 & 50.90 & 81.28 & 69.18 & 67.06 & 81.13 & 62.76 \\
\hline Median & 74.90 & 61.80 & 50.70 & 37.50 & 51.60 & 82.50 & 71.00 & 68.70 & 83.80 & 63.40 \\
\hline Max. & 94.30 & 84.60 & 80.10 & 78.40 & 89.80 & 100.00 & 94.00 & 94.20 & 100.00 & 80.50 \\
\hline Min & 41.80 & 31.10 & 25.00 & 0.00 & 14.90 & 44.20 & 29.50 & 2.40 & 31.60 & 39.40 \\
\hline Std. Dev. & 11.23 & 8.57 & 9.91 & 15.84 & 12.52 & 10.77 & 12.94 & 12.28 & 11.19 & 7.31 \\
\hline CV & 0.15 & 0.14 & 0.19 & 0.41 & 0.25 & 0.13 & 0.19 & 0.18 & 0.14 & 0.12 \\
\hline Skewness & -0.45 & -0.15 & 0.12 & 0.25 & 0.06 & -0.77 & -0.69 & -1.04 & -1.12 & -0.57 \\
\hline Kurtosis & 2.70 & 3.63 & 3.24 & 2.88 & 3.34 & 3.58 & 3.18 & 6.36 & 4.66 & 3.33 \\
\hline J-B test & 9.24 & 4.97 & 1.13 & 2.63 & 1.28 & 27.45 & 19.89 & 159.44 & 77.67 & 14.62 \\
\hline Prob. & 0.0099 & 0.0831 & 0.5670 & 0.2686 & 0.5280 & 0.0000 & 0.0000 & 0.0000 & 0.0000 & 0.0007 \\
\hline Obs. & 245 & 245 & 245 & 245 & 245 & 245 & 245 & 245 & 239 & 245 \\
\hline
\end{tabular}

The next three lowest average of sub-indices are X4 (Business Development Programmes, 38.57),X3 (Interaction between Local Government and Private Sector, 50.90), and X5 (Capability and Integrity of Local Government Officials, 50.94). The latter is slightly similar to that in 2007. They imply that capability and integrity of local government officials to interact with private sectors in order to promote business are quite low even thoughthey have successfully maintained security and conflict resolutions in their regions. 
The overall local economic governance index on the average is 62.76 in 2011, almost close to 61.72 in 2007. In general, all sub-indicesandtotal index of local economic governance during 2007-2011 tend to stagnate. Visual inspection of Kernel density as displayed in Figure 3 supports that preliminary conclusion. The non-parametric densities have been computed using Gaussian Kernel, with optimal bandwidth selected for each case. In the starting year, the shape is closely to be a normal distribution and the probability density is slightly right-skewed. It is also notable that a local peak at the right of the mode, suggesting some degree of polarization for this specific year.

In 2011, the progress experienced in the highest part of the distribution is noticeable, since the probability mass has partly shifted slightly to the right. Even though the probability mass has remained unchanged, two local peaks at the center now appear, suggesting that some degree of polarization of the higher governance regions for this specific year was also occurred. Basically, there is no significant difference between the shapes of local economic governance total index distribution in 2007 and 2011. In general, almostallsub-indicesandthe total index are normally distributed as indicated by the Jarque-Berra test as delivered previously in Table 3 and 4.

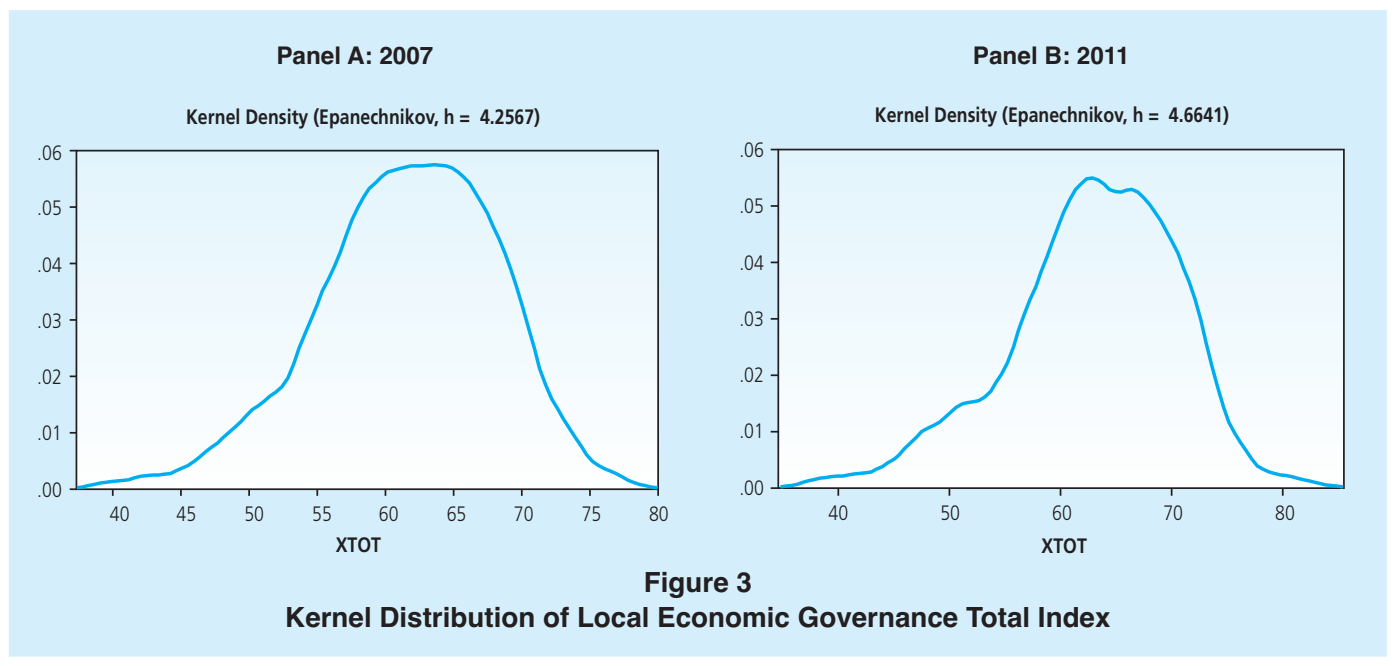

Table 5 presents the simple pair wise correlations matrix between the governance subindices. The bottom-left part presents for 2007 and the upper-right part presents for 2011. Almost all sub-indices being positively correlated with most of the other sub-indices, but, usually negatively with the Business Development Programs sub-index. In 2007, for example, sub-index X1 (Land Accessibility) is negatively correlated with X4 (Business Development Program). This conditional so occurs in relation to sub-indices $X 4, X 6, X 7, X 8$, and $X 9$. This implies that the land remains areal obstacle for the economic developmen tin the area as found by Mahi (2009). 
In 2011 the phenomena did not shift. Land Accessibility (X1) is still a serious constraint, especially related toX4 as well as the Quality of Local Regulations(X9). The X4 was also significantly negatively correlated with the X6 (Local Taxes and Local Retributions and other Transaction Costs). The Quality of Local Regulations and Local Taxes and Levies are fully under the control of local governments so that appropriate adjustments can be done immediately. This probably means that the local government is less responsive in capturing the economic problems that emerged int he own area.

The two highest positive correlations are X3 with X5 and X2 with X3 in 2007. In 2011 the two highest positive correlations are $X 3$ with $X 5$ and $X 1$ with $X 6$. They inform us that Capability and Integrity of Local Government Officials (X5) matters in relation to Interaction between Local Government and Private Sector (X3) as well as Business Licensing (X2). The broader land accessibility tends to increase the local tax and levies revenues.

Those large correlations suggest that it may be possible to summarize these governance concepts with fewer variables. Moreover, the fact that one sub-index - Business Development Services - is negatively correlated four other sub-indices is peculiar. Meanwhile, the small positive correlations between these sub-indices since the concepts of governance inevitably overlap to some extent (McCulloch and Malesky, 2010).

\begin{tabular}{|c|c|c|c|c|c|c|c|c|c|}
\hline \multicolumn{10}{|c|}{$\begin{array}{l}\text { Table } 6 . \\
\text { Pair Wise Correlationbetween Sub-Indices of Local Economic Governance. 2007-2011 }\end{array}$} \\
\hline Sub-Indices & $\mathrm{X} 1$ & $\mathrm{X} 2$ & X3 & X4 & X5 & X6 & $x 7$ & X8 & X9 \\
\hline $\mathrm{X} 1$ & 1.00 & 0.22 & 0.23 & -0.30 & 0.28 & 0.49 & 0.16 & 0.48 & -0.08 \\
\hline $\mathrm{x} 2$ & 0.15 & 1.00 & 0.38 & 0.21 & 0.20 & 0.25 & 0.42 & 0.33 & 0.02 \\
\hline $\mathrm{X} 3$ & 0.10 & 0.55 & 1.00 & 0.22 & 0.69 & 0.11 & 0.35 & 0.38 & -0.04 \\
\hline $\mathrm{X} 4$ & -0.37 & 0.16 & 0.20 & 1.00 & 0.06 & -0.23 & 0.13 & -0.09 & 0.00 \\
\hline$\times 5$ & 0.18 & 0.51 & 0.78 & 0.12 & 1.00 & 0.15 & 0.26 & 0.39 & -0.01 \\
\hline$x 6$ & 0.45 & 0.24 & 0.24 & -0.19 & 0.31 & 1.00 & 0.07 & 0.30 & -0.04 \\
\hline$\times 7$ & 0.24 & 0.33 & 0.10 & -0.09 & 0.23 & 0.32 & 1.00 & 0.00 & 0.02 \\
\hline X8 & 0.46 & 0.44 & 0.43 & -0.18 & 0.43 & 0.53 & 0.31 & 1.00 & 0.00 \\
\hline X9 & 0.12 & 0.00 & -0.10 & -0.04 & -0.05 & 0.08 & 0.07 & -0.03 & 1.00 \\
\hline
\end{tabular}

So far, we have talked about the local economic governance in Indonesia within the comparative statics frameworks. Isthe phenomenon of local economic governance in each region as occurred in Tables 2 through 5 above temporary (that can still be changing in the long term) or permanent in nature? Will there be a dramatic fundamental change in the local economic 
governance inaddressing theeconomic issuesthat emerge in each region? The lastsectionwill answerthat questionmore forcefully.

To answer these questions, some adjustments are done. This is because the districts/ municipalities sampled by KPPOD in a particular year could not be covered again in the next annual survey. For this reason, the selected regions are districts/municipalities that were sampled in 2007 and also surveyed in 2011. In this circumstance, there are 62 selected districts/ municipalities. I then classify arbitrary them into four categories, (a) verygood (ranked 1-10), (b) good (ranked 11-50), (c) fair (ranked 51-100), and (d) bad (ratings greater than 100). The classification is carried out respectively for 2007 and 2011. The results are presented in Table 6 below.

Table 6 shows there are only three regions (as highlighted in Table 1, namely Blitar, Magetan, and Probolinggo) that occupy the top ranking from 1 to 10 (state A) either in 2007or in 2011. The classification $B$ populated 6 regions with a rating of 11 to 50 . The main diagonal from upper-left to lower-rightis by itself, shows the degree of persistence in the relative position of the district/municipalities is high, suggesting the permanent change of local economic governance. This means that there were no significant increases in ratings more than 50 percent (32 regions) of the observed districts/municipalities.

\begin{tabular}{|c|c|c|c|c|c|c|}
\hline \multicolumn{7}{|c|}{$\begin{array}{l}\text { Table } 6 . \\
\begin{array}{l}\text { The Observed Frequencies and Transition Matrix of Local Economic Governance Total Index } \\
\text { in Selected Districts/Municipalities. 2007-2011 }\end{array}\end{array}$} \\
\hline \multirow{2}{*}{ Ye a r } & \multirow[b]{2}{*}{ State } & \multicolumn{5}{|c|}{2011} \\
\hline & & A & B & C & D & Total \\
\hline \multirow{6}{*}{2007} & A & $3(0.5000)$ & $0(0.0000)$ & $3(0.5000)$ & $0(0.0000)$ & 6 \\
\hline & B & $1(0.0714)$ & $6(0.4286)$ & $2(0.1429)$ & $5(0.3571)$ & 14 \\
\hline & C & $0(0.0000)$ & $3(0.2000)$ & $7(0.4667)$ & $5(0.3333)$ & 15 \\
\hline & D & $0(0.0000)$ & $6(0.2222)$ & $4(0.1482)$ & $17(0.6296)$ & 27 \\
\hline & Total & 4 & 15 & 16 & 27 & 62 \\
\hline & Ergodic & 0.0233 & 0.1629 & 0.1454 & 0.2879 & \\
\hline
\end{tabular}

Only one region (Probolinggo municipality) that in 2007 still was in state B jumped to category A. The other positive changes occurred for three regions. They in 2007 were able to move to occupy from state $C$ to state $B$ in 2011 . Four regions that originally were in category $D$ was able to ascend to the rank position of $C$ in 2011. In fact, there are six regions that still in classification D in 2007 can jump into the category B in 2011.

This contrasts with 15 other regions that experienced a decrease in their position. For example, there are three regions in 2007 is located at position state $A$ then decreased even into 
the predicate C. Overall, there are evidently no jumps from state D to A or C to A (or vice versa) are visible - there are no governance shift miracles in this sample — and thus the degree of mobility is limited to the better category, consistent with the study of McCulloch and Malesky (2010).

The transition is assumed to continue to evolve through the mechanism of the Markov chains until it reaches a steady state position. The last line of Table 6 presents the probability of ergodic occurrence. The calculation result shows that there is little opportunity (2.33 percent) in the long-term for the regions to keep staying in the ten top rankings. The probability to reach the category Band Care also relatively low, approximately 16.29 and 14.54 percent respectively. This implies that the local government has not reached yet at the optimum level in improving the regional economic governance, even though they already have been in the good rankings.

The greatest probability is on the classification $D$ (ranked in over 100). The probability ofnot getting out from D positionis nearly 28.79 percent. The highest persistence in the lowest state of regions should, no doubt, be a matter of concern for both academic and policy makers: it may be hiding some kind of poor governance trap. It presents that because of structural constrains those regions cannot grow as fast as others. As a result, their position remains unchanged. Thus, tomove out from thepredicateof bad governance into a better category, it requiresthe local government's entrepreneurial touches tosolvethe excessive problems typically occur in each region.

The current results agree with the intuitions obtained from the visual inspection of the graphs above, since they do not predict polarization among districts/municipalities in the years 2007-2011 but, rather, some kind of concentration around the average values. Nevertheless, these results may also suggest some sort of geographical externality, along the lines of Krugman (1991a, 1991b). Spillovers among neighboring regions may foster the governance development of the contiguous areas. In particular, when examining the region in the highest states in 2007 and 2011, a shift of the highest governance index were located to the west of the country can be observed, such as Java, Sumatera, and Bali, while in the same period some well-off regions were located in other areas. To sum up, all of theanalytical tools applied in this paper provide a strong indicationthat there is no significant improvement of the local economic governance in the case of district/municipalities in Indonesia.

\section{CONCLUSION}

This paper tries toobserve thelocal economic governance in the case of districts/municipalities in Indonesia through various measures of economic governance index. Observations for 2007 and 2011 showed that there were no significant changes in the performance of local economic governance. The unchanged ingovernance of local economic performance due to land issues, 
business development programs, taxes and levies and other transaction costs, security, and local regulations.

These results suggest improving the local economic governance to create conducive investment climate to support the growth of economic activities. An industry in a particular area will improve if the region has a favor investment climate. In terms of improving the investment climate, the local governments should focus their economic development primarily on providing the quality of infrastructur ein the area, especially land accessibility and business development program. The central government can encourage some policies for national infrastructure improvements and provide stimulation for the local government to give priority to infrastructure provision.

Finally, it should be noted that the local economic governance is a necessary condition for the creation of regional economic growth, but not a sufficient condition for the improvement of regional economic performance. It seems that the local governance can be a source of explanatory (symptoms) forregional economic growth, rather than the causes of regional economic performance. This also confirms that the various efforts to improve local governance require greater attention to understanding how the structural characteristics that makes up the regional political economy which in turn affects the performance of the economy in line with decentralization and regional autonomy.

The local economic governance particularly in Indonesia is still open and relevant to analyze. This paper used two sample point data only. The further investigation can be done using more sophisticated devises. Employing most recent time series data and applying, for example, Markov chains method for continuous variable, are advisable so that the transition dynamics of local economic governance will be more accurate for policy makers to address the related problems. 


\section{REFERENCES}

Acemoglu D., S. Johnson, and S. Robinson, (2005), "Institutions as the Fundamental Cause of Long-Run Growth" in P. Aghion and S. Durlauf, (Eds.), Handbook of Economic Growth, Volume 1, Part A, Elsevier: 385-472.

Alt, J.E. and K.A. Shepsle, (Eds.), (1990), Perspectives on Positive Political Economy, Cambridge: Cambridge University Press.

Amemiya, T., (1985), Advanced Econometrics, Basil Blackwell, Oxford.

Ardagna, S., and A. Lusardi, (2008), "Explaining International Differences in Entrepreneurship: The Role of Individual Characteristics and Regulatory Constraints", NBER Working Paper Series, No. 14012, May.

Banerjee, A. and L. Iyer, (2005), "History, Institutions, and Economic Performance: the Legacy of Colonial Land Tenure Systems in India", American Economic Review, 95(4), 1190-213.

Bardhan, P., (1984),-The Political Economy of Development in India. Oxford: Basil Blackwell.

Bates, R.H., (2001), Prosperity and Violence: The Political Economy of Development, New York: W.W. Norton.

Bhagwati, J.N., (1982), "Directly Unproductive, Profit-Seeking (DUP) Activities", Journal of Political Economy,90(5): 988-1002.

Cali, M., (2009), "Do Effective State Business Relations Matter for Economic Growth? Evidence from Indian States", Manchester, Research ProgramConsortium for Improving Institutions for Pro-Poor Growth (IPPG).

Chibba, M., (2009), "Governance and Development, the Current Role of Theory, Policy and Practice", World Economics, Vol. 10, No. 2, April-June 2009: 78-108.

Colander, D.C. (Ed.), (1984), Neoclassical Political Economy: The Analysis of Rent-Seeking and DUP Activities, Cambridge Massachusetts: Ballinger Publishing Co.

Djankov, S., R. Porta, F. Silanes.and A. Shleifer, (2002), "The Regulation of Entry", Quarterly Journal of Economics, 117: 1-37.

Di Tella, R. and E. Schargrodsky, (2003), "The Role of Wages and Auditing during a Crackdown on Corruption in the City of Buenos Aires", Journal of Law and Economics,46:269-92. 
Di Tella, R., S. Galiani, and E. Schargrodsky, (2007), "The Formation of Beliefs: Evidence from the Allocation of Land Titles to Squatters", The Quarterly Journal of Economics, Vol. 122, No. 1.

Dixit, A.K.,(2001), "On Modes of Economic Governance", CESifo Working Paper Series No. 589.

Field, E., (2007), "Entitled to Work: Urban Tenure Security and Labor Supply in Peru", The Quarterly Journal of Economics, Vol. 122, No. 4 (November): 1561-602.

Fisman, R., (2001), "Estimating the Value of Political Connections", American Economic Review, 91(4): 1095-102.

Galiani, S. and E. Schargrodsky, (2010),-“Property Rights for the Poor: Effects of Land Titling, Journal of Public Economics,94: 700-29.

Golden, M. and L. Picci, (2005), "Proposal for a New Measure of Corruption, Illustrated with Italian Data", Economics and Politics, 17:37-75.

Hariyoga, H., (2009), "The Determining Factors of Local Economic Performance, Challenges, and Obstacles", paper presented in the" Focus Group Discussion in the Coordinating Ministry of Economy", Jakarta, November 12.

Helpman, E., (2008), Institutions and Economic Performance, Cambridge, Harvard University Press.

Istiandari R., (2009), "Local Economic Governance and Social Welfare in Indonesia", KPPOD Brief, May-June.

Kaufmann, D., A. Kraay, and P. Zoido-Lobatón, (1999), "Governance Matters", World Bank Policy Working Paper No. 2196. World Bank: Washington.

Kaufmann, D., A. Kraay, and P. Zoido-Lobaton, (2000), "Governance Matters: From Measurement to Action", Finance and Development, 37(2), Washington DC: International Monetary Fund.

Kaufmann, D., A. Kraay, and M. Mastruzzi, (2005), Governance Matters IV: Governance Indicators for 1996-2004, World Bank Policy Research Working Paper.

Knack, S. and P. Keefer, (1995), "Institutions and Economic Performance: Cross-Country Tests Using Alternative Institutional Measures", Economics and Politics,7(3):207-27.

Knack, S. and P. Keefer, (1997), "Why Don't Poor Countries Catch Up?, A Cross-National Test of an Institutional Explanation", Economic Inquiry,35(3):590-602.

Knack, S., (Ed.), (2003), Democracy, Governance, and Growth, Ann Arbor: The University of Michigan Press.

Kong, T., (2011), "Governance Quality and Economic Growth", College of Business and Economics, Australian National University Working Paper No: 537, January. 
KPPOD, (2011), KPPOD Brief, January- March 2011.

Krueger, A.O., (1974), "The Political Economy of the Rent-Seeking Society", American Economic Review,64(3): 291-303.

Krugman, P., (1991a), "Increasing Returns and Economic Geography", Journal of Political Economy, 99(3): 483-99.

Krugman, P., (1991b), Geography and Trade, MIT Press, Cambridge.

Kuncoro, H., (2005), "The Impact of Intergovernmental Transfer on Fiscal Performance, Economic Growth, and Regional Disparity in Indonesia", Unpublished Dissertation, UniversitasGadjahMada, Yogyakarta.

Kuncoro, H. and Suryanto, (2003), "Regional Economic Growth Dynamics in Indonesia",

The Journal of Accounting, Management, and Economics Research, Faculty of Economics UTY, Yogyakarta, Vol. 3, No. 2, September: 169-85.

Laeven, L., and C. Woodruff, (2007), "The Quality of the Legal System, Firm Ownership, and Firm Size", Review of Economics and Statistics,89.4: 601-14.

Lal, D. and H. Myint, (1996), The Political Economy of Poverty, Equity, and Growth: A Comparative Study, Oxford: Clarendon Press.

Lewis, B., (2003), "Tax and Charge Creation by Regional Governments under Fiscal Decentralisation: Estimates and Explanations", Bulletin of Indonesian Economic Studies, $39(2)$.

Lucas, R., (1988), "On the Mechanics of Economic Development", Journal of Monetary Economics, 22: 3-42.

Mahi, B.R., (2009), "Geographical Concentration of Industries: The Impact of Governance and Investment Climate in Region", paper presented in the" Focus Group Discussion in the Coordinating Ministry of Economy", Jakarta, November 12.

Malesky, E. and K. Samphantharak, (2008), "Predictable Corruption and Investment Strategy: Evidence from a Natural Experiment and Survey of Cambodian Entrepreneurs", Quarterly Journal of Political Science 3, 3: 227-67.

Malesky, E. and M. Taussig,(2009), "Out of the Gray: The Impact of Provincial Institutions on Business Formalization in Vietnam",Journal of East Asian Studies, 9: 249-90.

McCulloch, N. and E. Malesky, (2010), “Does Better Local Government Governance Induce Local Economic Growth Performance in Indonesia?", working paper, KPPOD, Institute of Development Studies, and AusAid. 
Mengistu, A.A. andB.K. Adhikary, (2011), "Does Good Governance Matter for FDI Inflows? Evidence from Asian Economies", Asia Pacific Business Review, Volume 17, Issue 3: 281-99. North, D.C., (1981), Structure and Change in Economic History, New York, W.W. Norton.

North, D.C., (1990), Institutions, Institutional Change, and Economic Performance, Cambridge University Press, UK.

Olken, B.A., (2007), "Monitoring Corruption: Evidence from a Field Experiment in Indonesia", Journal of Political Economy, 115, (2): 200-49.

Pambudhi, A., (2009), "Government Governance and Economic Growth", paper presented in the" Focus Group Discussionin the Coordinating Ministry of Economy", Jakarta, November 12.

Pepinsky, T.C. and M.M. Wihardja, (2009), "Decentralization and Economic Performance in Indonesia", Paper presented at the 2009 Annual Meeting of the American Political Science Association. Chicago.

Posner, R.A., (1975), "The Social Costs of Monopoly and Regulation", Journal of Political Economy,83(4): 807-27.

Quibria, M.G., (2006), “Does Governance Matter? Yes, No, or Maybe: Some Evidence from Developing Asia", Kyklos, 59(1): 99-114.

Romer, P., (1986), "Increasing Returns and Long Run Growth", Journal of Political Economy, 94: 1002-37.

Romer, P., (1990), "Endogenous Technological Change", Journal of Political Economy, 98: S71S102.

Romer, D., (1996), Advanced Macroeconomics, McGraw-Hill Co., Inc., New York.

Sebayang, D. and H.Kuncoro, (2011), "The Role of Business Development Service in Development Small Medium Enterprise Center in Order to Build a Regional Economic Partnership", paper presented in the International Conference "Political Economy of Trade Liberalization in East Asia", Facultyof Economicsand Business, UniversitasBrawijaya, Malang, November,24-25.

Silverman, B.W., (1986), "Density Estimation for Statistics and Data Analysis, Chapman and Hall, New York.

Thomas, M.A., (2007), "What Do the Worldwide Governance Indicators Measure?" ,European Journal of Development Research, 22 (1): 31-54.

Wei, S.J., (2000), "Local Corruption and Global Capital Flows", Brookings Papers on Economic Activity (2): 303-54. 
Weiss, T.G., (2005), "Governance, Good Governance, and Global Governance: Conceptual and Actual Challenges," in R. Wilkinson, (Ed.), the Global Governance Reader, New York: Routledge.

Williamson, O., (1975), Markets and Hierarchies, Analysis and Antitrust Implications: A Study in the Economics of Internal Organization, New York: Free Press.

Williamson, O., (1985), The Economic Institutions of Capitalism: Firms, Markets, and Relational Contracting, New York: Free Press.

World Bank, (2005), Governance Indicators: 1996-2004,Washington DC: World Bank. 
This page is intentionally left blank 